\title{
Purification of Ovalbumin From Egg White Using Molecular Imprinted Cryogels
}

\section{Moleküler Baskılanmış Kriyojeller Kullanılarak Yumurta Akından Ovalbumin Saflaştırılması}

\section{Duygu Çimen ${ }^{\bullet}$ and Adil Denizli*৫}

Hacettepe University, Department of Chemistry, Beytepe, Ankara, Turkey.

\section{ABSTRACT}

\begin{abstract}
$\mathrm{n}$ recent years, food allergy is one of the most important problems worldwide. Ovalbumin is one of the main allergens found in egg whites. In this study, ovalbumin imprinted and non-imprinted poly(hydroxyethyl methacrylate-methacrylic acid (poly(HEMA-MAA)) cryogels were synthesized using molecular imprinting method. After characterization of ovalbumin imprinted cryogels, the effect of flow rate, $\mathrm{pH}$ buffer, einitial ovalbumin concentration, ionic strength, and temperature parameters are examined. The maximum ovalbumin adsorption amount was determined to be $37.78 \mathrm{mg} / \mathrm{g}$ of ovalbumin imprinted cryogels at $\mathrm{pH} 5.5,25^{\circ} \mathrm{C}$ and a flow rate of $0.5 \mathrm{~mL} / \mathrm{min}$. The selectivity studies of ovalbumin imprinted and non-imprinted cryogels were performed using lysozyme and transferrin as competitor molecules. In addition, reusability experiments of ovalbumin imprinted cryogels were performed. The purity of ovalbumin was determined from egg white using sodium-dodecyl sulfate polyacrylamide gel electrophoresis (SDS-PAGE). The purity of ovalbumin was found to be approximately $85.4 \%$.
\end{abstract}

\section{Key Words}

Ovalbumin, cryogel, molecular imprinting method, purification.

On yıllarda, dünya çapında gıda alerjisi en önemli sorunlardan biridir. Ovalbumin yumurta akında bulunan ana alerjanlardan biridir. Bu çalışmada, ovalbumin baskılanmış ve baskılanmamış poli(hidroksietil metakrilat-metakrilik asit) poli(HEMA-MAA) kriyojeller moleküler baskılama yöntemi kullanılarak sentezlenmiştir. Ovalbumin baskılanmış kriyojellerin karakterizasyonundan sonra, akış hızı, pH tamponu, ilk ovalbümin konsantrasyonu, iyonik kuvvet ve sıcaklık parametrelerinin etkisi incelenir. Maksimum ovalbumin adsorpsiyon miktarı, ovalbumin baskılanmış kriyojel için pH 5.5, $25^{\circ} \mathrm{C}$ ve $0.5 \mathrm{~mL} / \mathrm{dk}$ akış hızında $37.78 \mathrm{mg} / \mathrm{g}$ olarak belirlenmiştir. Ovalbumin baskılanmış ve baskılanmamış kriyojellerin seçicilik çalışmaları, yarışmacı moleküller olarak lizozim ve transferrin kullanılarak gerçekleştirilmiştir. Ayrıca ovalbumin baskılanmış kriyojellerin yeniden kullanılabilirlik deneyleri gerçekleştirilmiştir. Ovalbuminin saflı̆̆ı, sodyum-dodesil sülfat poliakrilamid jel elektroforezi (SDSPAGE) kullanılarak yumurta akından belirlenmiştir. Ovalbuminin saflığı yaklaşık\% 85.4 bulunmuştur.

\section{Anahtar Kelimeler}

Ovalbumin, kriyogel, moleküler baskılama yöntemi, saflaştırma.

Article History: Received: Apr 17, 2021; Revised: May 10, 2021; Accepted: Jul 27, 2021; Available Online: Jul $27,2021$.

DOI: https://doi.org/10.15671/hjbc.918700

Correspondence to: A. Denizli, Hacettepe University, Department of Chemistry, Beytepe, Ankara, Turkey.

E-Mail: denizli@hacettepe.edu.tr 


\section{INTRODUCTION}

Cood allergy is a major health problem worldwide. - Ovalbumin, the most abundant protein in egg white, is known as the main allergen [1-4]. Ovalbumin constitutes $60-65 \%$ of the total protein in egg white. Ovalbumin is a complex glycoprotein consisting of 386 amino acids with a molecular weight of $44 \mathrm{kDa}$. Ovalbumin contains six cysteines with a single disulfide bond between Cys74 and Cys121 [5-10]. It causes food allergies with the most common immunoglobulin $E$, especially in infants and young children [11-18]. Today, typical methods such as ovalbumin electrophoresis, ion exchange chromatography, size exclusion liquid chromatography, ultrafiltration obtained from egg white are used [19-21]. However, some of these methods are multi-stage and costly. Also, extracting and purifying proteins from a complex matrix such as egg whites is a difficult task.

Cryogels are gel matrices prepared by freezing solutions containing monomeric or polymeric precursors, in part under freezing conditions. Wide interconnected porous mesh structure is the main characteristic feature of cryogels [22,23]. Cryogels show very low flow resistance due to their spongy morphology and macroporous structure, and practically allow diffusion of soluble matter of any size without hindering. As macroporous substances, cryogels are used as a matrix, as they allow not only diffusion of small molecular weight solutes, but also macromolecules and cells without hindering diffusion $[24,25]$. This is due to the interconnected structure of the macropores, and, the spongy and elastic morphology of the cryogels as a whole. The most common application areas of cryogels are separation, catalysis, and affinity chromatography [26-29]. Molecularly imprinted polymers are often used as recognition elements in food, life, medicine, and environmental science [3033]. One of the application areas of molecularly imprinted polymers are cryogels as affinity support materials $[33,35]$. In recent years, molecularly imprinted cryogels are utilized in determining the biologically active molecules such as drugs, proteins, peptides, amino acids thanks to their higher selectivities [36-39].

In this study, we prepared ovalbumin imprinted and non-imprinted poly(hydroxyethyl methacrylate-methacrylic acid poly(HEMA-MAA) cryogels for purification of ovalbumin from egg white. Characterization studies of ovalbumin imprinted and non-imprinted cryogels were carried out with fourier transform infrared spect- roscopy (FTIR), swelling degree, surface area and scanning electron microscopy (SEM) measurements. In the adsorption studies of ovalbumin imprinted cryogels, the effects of $\mathrm{pH}$, initial ovalbumin concentration, temperature, ionic strength, flow rate, and reusability were investigated with continuous system.

\section{MATERIALS and METHODS}

\section{Chemicals}

Ammonium persulfate (APS), ovalbumin (OVA), methacrylic acid (MAA), 2-hydroxyethyl methacrylate (HEMA), N, N'-tetramethylethylenediamine (TEMED) and $\mathrm{N}, \mathrm{N}^{\prime}$-methylene bisacrylamide (MBAAm) were purchased from Merck (Switzerland). In the selectivity studies, lysozyme (Lyz) and transferrin (Tf) were obtained from Sigma (St. Louis, USA). During the experimental studies, deionized water was used.

\section{Preparation of Ovalbumin imprinted and non- imprinted cryogels}

Complexes with 1:1, 1:2 and 1:3 M different molar ratios of monomer:template (MAA:OVA) were prepared for the preparation of ovalbumin imprinted (MIP) and nonimprinted (NIP) cryogels. Three different OVA imprinted cryogels were synthesized with MAA:OVA complexes at each different molar ratio. MAA:OVA complex in a ratio of 1:1 M for cryogel named MIP-1, MAA:OVA complex in molar ratio of 1:2 $\mathrm{M}$ for cryogel named MIP-2 and MAA:OVA complex in molar ratio of $1: 3 \mathrm{M}$ for cryogel named MIP-3 were prepared for the synthesis of 3 different OVA imprinted cryogels. HEMA and MBAAm were dissolved in $10 \mathrm{~mL}$ of deionized water and was prepared separately for each 3 different OVA imprinted cryogels. Three different molar ratio of MAA:OVA complexes were added to separately this monomer solution. TEMED (1\%) and APS, 1\% were used as the initiator/ activator pairs. These mixture for each OVA imprinted poly(HEMA-MAA) cryogels were placed in separately 5 $\mathrm{mL}$ plastic bottom-sealed syringes and frozen for $24 \mathrm{~h}$ at $-12^{\circ} \mathrm{C}$. Non-imprinted cryogel was synthesized by the same polymerization procedure without using OVA.

\section{Characterization Studies}

The characterization studies of OVA imprinted and non-imprinted poly(HEMA-MAA) cryogels were carried out with scanning electron microscopy (SEM) measurements, fourier-transform infrared spectroscopy (FTIR), surface area, macroporosity and swelling degree (SD). FTIR spectra of poly(hydroxyethyl methacr- 
ylate-methacrylic acid) cryogels were examined in the range $600-4000 \mathrm{~cm}^{-1}$ using a FTIR spectrometer. The specific surface areas of the OVA imprinted and nonimprinted cryogels were determined by multipoint Brunauer-Emmett-Teller (BET) method (Quantachrome, Nova 2200E, USA). SEM measurements were made to examine the surface morphology of OVA imprinted poly(hydroxyethyl methacrylate-methacrylic acid) cryogels. Firstly, the cryogels were dried $\left(m_{\text {dried }}\right)$ and weighed for the swelling properties of OVA imprinted and nonimprinted cryogels. Deionized water was placed in a 20 $\mathrm{mL}$ beaker and placed in cryogel. The wet cryogel was removed from beaker, wiped and weighed $\left(m_{\text {wet }}\right)$. Macroporosity is calculated using the weight of the cryogel in its pores when the water is swollen and after being squeezed. The swelling degree and macroporosity were determined using Eq $(1,2)$.

Swelling degree $=\frac{\mathrm{W}_{0}-\mathrm{W}_{\mathrm{sw}}}{\mathrm{W}_{0}}$

Macroporosity $\%=\frac{\mathrm{W}_{\mathrm{sw}}-\mathrm{W}_{\mathrm{sq}}}{\mathrm{W}}$

\section{Adsorption Studies}

The effects of temperature, ionic strength, $\mathrm{pH}$, flow rate and initial concentration on the ovalbumin adsorption capacity were studied for OVA imprinted cryogels. The effect of $\mathrm{pH}$ on the adsorption capacity was studied in acetate and phosphate buffers pH 3.0-8.0 at ovalbumin concentration of $0.5 \mathrm{mg} / \mathrm{mL}$. The adsorption capacity of OVA imprinted cryogels was determined by performing along $2 \mathrm{~h}$ analyzes by performing adsorption studies in the range of OVA concentration of $0.1-2.5 \mathrm{mg} / \mathrm{mL}$. The effect of temperature $\left(4-45^{\circ} \mathrm{C}\right)$, flow rate $(0.5-2.5 \mathrm{~mL} /$ $\mathrm{min})$ and ionic strength $(0-1.0 \mathrm{M}, \mathrm{NaCl})$ on the adsorption capacities were also investigated by using OVA imprinting cryogels. The amount of the adsorbed ovalbumin was determined spectrophotometrically at $280 \mathrm{~nm}$ wavelength. Desorption studies of OVA imprinted cryogel were carried out using $1.0 \mathrm{M} \mathrm{NaCl}$ solution. Finally, OVA imprinted cryogels were repeated 10 times using the same cryogel in adsorption-desorption studies.

For purification of ovalbumin from egg white, the egg white was first separated from the egg yolk. After, the globulins were precipitated by adding $2 \mathrm{~mL}$ of $50 \%(\mathrm{v} / \mathrm{v})$ saturated ammonium sulfate, and the precipitate was centrifuged at $3000 \times \mathrm{xg}$ for $30 \mathrm{~min}$. The $\mathrm{pH}$ of the supernatant was adjusted to $\mathrm{pH} 4.6$ by adding $2.0 \mathrm{M}$ acetic acid and centrifuged again at $3000 x g$ for 30 min. After centrifugation, the precipitate containing ovalbumin was suspended in $\mathrm{pH} 7.0$ phosphate buffer. SDS-PAGE analysis was used for ovalbumin purity from egg white. For SDS-PAGE analysis, $12 \%$ separation gel $(9 \times 7.5 \mathrm{~cm})$ was used and electrophoresis was operated at $110 \mathrm{~V}$ for $2 \mathrm{~h}$. After analysis, stacking gels (\%6) were prepared and stained with coomassie brillant prepared in water-acetic acid-methanol mixture [4]. The purity of ovalbumin from egg white was analysed by SDS-PAGE using $12 \%$ separating gel $[22,40]$.

\section{Selectivity experiments}

One of the most important features of molecular imprinting method is that cavities of the imprinted molecule are formed on the polymer surface. Ovalbumin, lysozyme, and transferrin are an important glycoproteins found in egg white. Lysozyme (Lyz, MW: 14.3 kDa) and transferrin (TF, MW: $55.8 \mathrm{kDa}$ ) molecules were chosen as competitive agents due to their presence with ovalbumin (OVA, MW: $44 \mathrm{kDa}$ ) in egg white as well as their molecular structure and weight [41]. Lyz and TF solutions were prepared at a concentration of $0.5 \mathrm{mg} /$ $\mathrm{mL}$ and adsorption studies were carried out on ovalbumin imprinted and non-imprinted cryogels. $K_{d}$ (distribution coefficients), $k$ (selectivity) and k' (relative selectivity coefficient) for Lyz and TF molecules relative to OVA molecules were calculated by following Eq $(3,4,5)$.

$\mathrm{Kd}=\left(\frac{\mathrm{C}_{\mathrm{i}}-\mathrm{C}_{\mathrm{f}}}{\mathrm{W}_{0}}\right) * \mathrm{~V} / \mathrm{m}$

$k=\frac{\mathrm{K}_{\mathrm{d}(\text { template protein })}}{\mathrm{K}_{\mathrm{d}(\text { competing protein })}}$

$\mathrm{k}^{\prime}=\frac{\mathrm{K}_{\mathrm{MIP}}}{\mathrm{K}_{\mathrm{NIP}}}$

The distribution coefficient $(\mathrm{mL} / \mathrm{g})$ is $K_{d^{\prime}}$ volume of the solution $(\mathrm{mL})$ is $V$, OVA concentrations $\left(\mathrm{mg} / \mathrm{mL}\right.$ ) is $C_{i}$ (initial) and $C_{f}($ final), and weight of polymer $(g)$ is $m$. 


\section{RESULTS and DISCUSSION}

\section{Characterization Studies}

OVA imprinted poly(HEMA-MAA) cryogels with code name (MIP-3) were observed aliphatic C-H stretch band at 2917 $\mathrm{cm}^{-1}$, carbonyl band at $1728 \mathrm{~cm}^{-1}$ and amide band 1541 $\mathrm{cm}^{-1}$. N-H stretching, $\mathrm{C}=\mathrm{O}$ of amide $\mathrm{I}$ and $\mathrm{C}-\mathrm{N}-\mathrm{H}$ of amide II vibration of the OVA was observed at $3201 \mathrm{~cm}^{-1}, 1652$ $\mathrm{cm}^{-1}$ and $1538 \mathrm{~cm}^{-1}$, respectively [42]. As can be seen from FTIR-ATR spectra, MAA monomer and ovalbumin molecule were found to enter the cryogel structure (Figure 1A). The surface morphology of OVA imprinted (MIP-3) cryogel was investigated by SEM. As clearly shown in Figure 1B, OVA imprinted cryogel has large continuous interconnected and homogeneous porous surface structure.

The swelling degree, macroporosity and specific area of ovalbumin imprinted and non-imprinted cryogels were characterized and given in Table 1 . When comparing OVA imprinted cryogels (code MIP-1, MIP-2 and MIP-3 cryogels) with non-imprinted (NIP) cryogels, it was observed that as the amount of ovalbumin increased, the degree of swelling and other variables increased. In addition, an increase in the specific surface area was observed with the increase in the imprinting ratio and caused an increase in water intake ratios

\section{Adsorption Experiments}

When the adsorption capacity of OVA imprinted and non-imprinted cryogels were compared, it was observed that the adsorption capacity of OVA imprinted cryogels was higher. This shows us that ovalbumin specific binding sites have been formed. The maximum imprinting factor value was observed at a 1:3 $\mathrm{M}$ ratio of MAA:OVA and all adsorption experiments were performed with OVA imprinted cryogel (MIP-3) synthesized at this molar ratio. In all experiments, ovalbumin concentration in the solution was determined spectrophotometrically at $280 \mathrm{~nm}$.

A
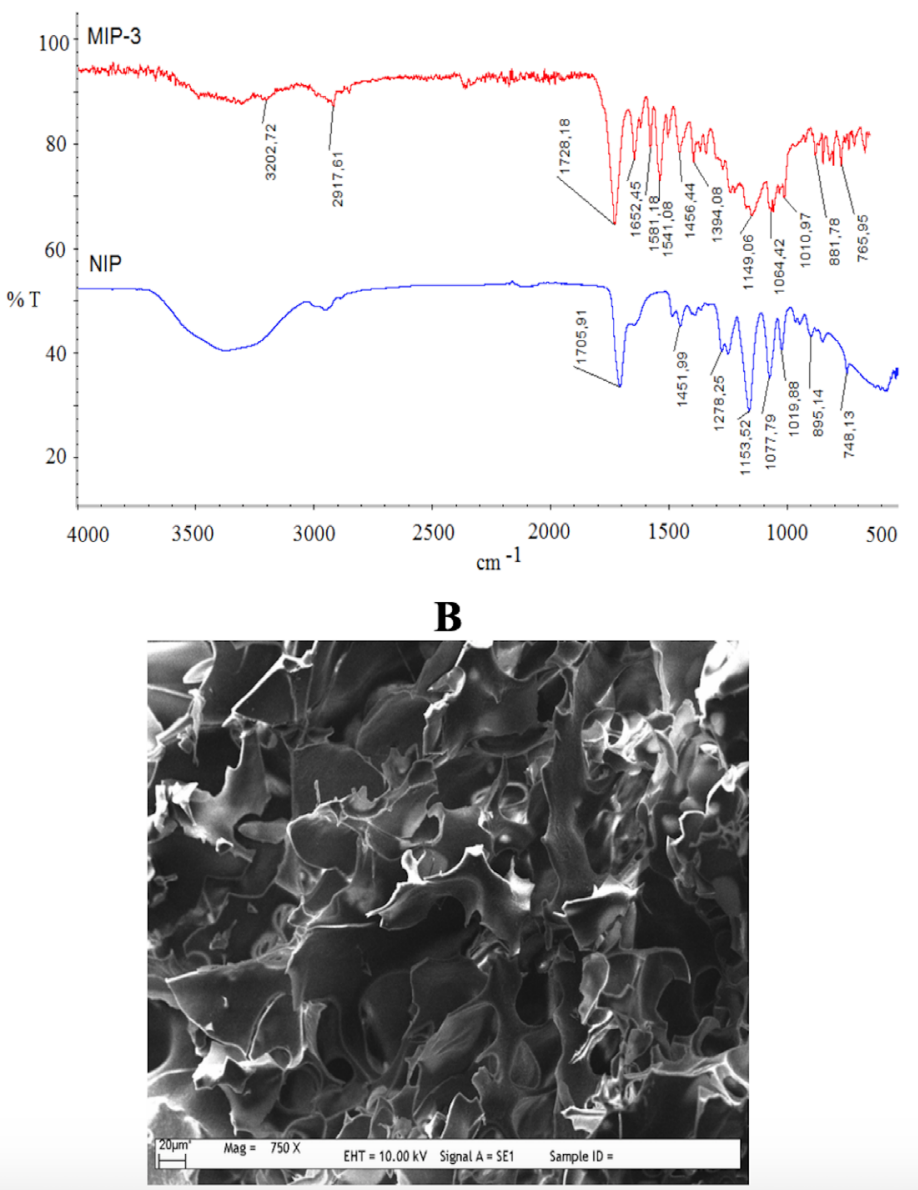

Figure 1. FTIR spectra of OVA imprinted (MIP-3) and non-imprinted (NIP) cryogels (A) and SEM image of OVA imprinted cryogel (B). 
Table 1. Physical properties of OVA imprinted (MIP) and non-imprinted (NIP) cryogels.

\begin{tabular}{cccc}
\hline $\begin{array}{c}\text { Polymer } \\
\text { Code }\end{array}$ & $\begin{array}{c}\text { Swelling } \\
\text { Degree }\end{array}$ & $\begin{array}{c}\text { Macroporosity } \\
(\%)\end{array}$ & $\begin{array}{c}\text { Surface } \\
\text { Area }\end{array}$ \\
\hline MIP-1 & $7.23 \mathrm{~g} \mathrm{H}_{2} \mathrm{O} / \mathrm{g}$ polymer & 71.15 & 25.7 \\
\hline MIP-2 & $9.02 \mathrm{~g} \mathrm{H}_{2} \mathrm{O} / \mathrm{g}$ polymer & 76.39 & 27.4 \\
\hline MIP-3 & $12.74 \mathrm{~g} \mathrm{H}_{2} \mathrm{O} / \mathrm{g}$ polymer & 81.84 & 32.5 \\
\hline NIP & $5.63 \mathrm{~g} \mathrm{H}_{2} \mathrm{O} / \mathrm{g}$ polymer & 56.26 & 21.6 \\
\hline
\end{tabular}

The effect of $\mathrm{pH}$ buffer on the adsorption capacity of OVA imprinted cryogel were performed by preparing different acetate $(\mathrm{pH} 3.0,4.0,5.0,5.5)$ and phosphate buffers ( $\mathrm{pH} 6.0,7.0$ and 8.0) at a concentration of 0.5 $\mathrm{mg} / \mathrm{mL}$ OVA. Figure 2 shows the effect of different buffer types on ovalbumin adsorption capacity with OVA imprinted cryogel. The maximum ovalbumin adsorption capacity was observed as $11.55 \mathrm{mg} / \mathrm{g}$ in pH 5.5 phosphate buffer [43]. The isoelectric point of ovalbumin molecule is in the range of 4.43-4.9. It has been observed that the solution $\mathrm{pH}$ has the highest adsorption capacity at $\mathrm{pH}$ where it is close to the isoelectric point.
The effect of flow rate on the ovalbumin adsorption capacity of OVA imprinted cryogels (MIP-3) was investigated at a concentration of $0.75 \mathrm{mg} / \mathrm{mL}$ ovalbumin. While the flow rate increased from $0.5 \mathrm{~mL} / \mathrm{min}$ to $2.5 \mathrm{~mL} / \mathrm{min}$, the adsorption capacity of OVA imprinted cryogels decreased from 17.38 to $5.44 \mathrm{mg} / \mathrm{g}$ polymer (Figure 3). It has been observed that the reason for the decrease in the adsorption capacity with the increase of the flow rate is due to the decrease in the retention time of ovalbumin [44]. The maximum ovalbumin adsorption capacity is determined as the lowest flow rate of $0.5 \mathrm{~mL} / \mathrm{min}$.

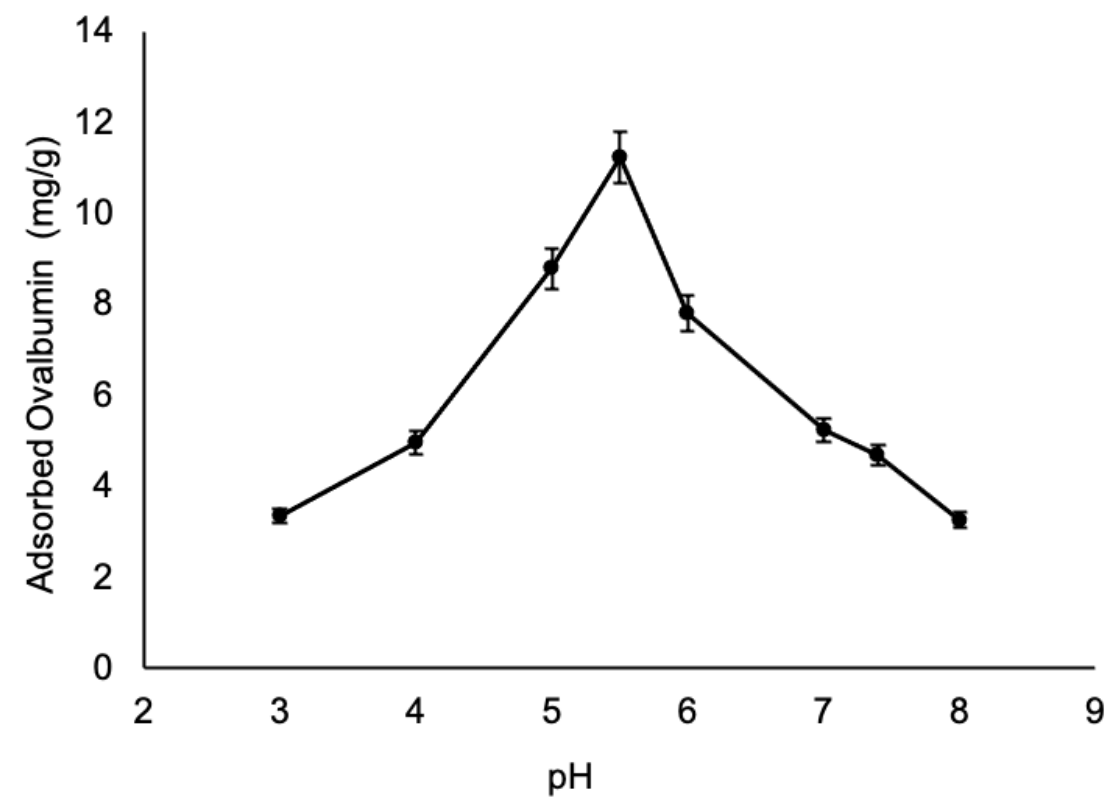

Figure 2. Effect of $\mathrm{pH}$ buffer (Flow rate: $0.5 \mathrm{~mL} / \mathrm{min}, \mathrm{T}: 25^{\circ} \mathrm{C}$ ). 


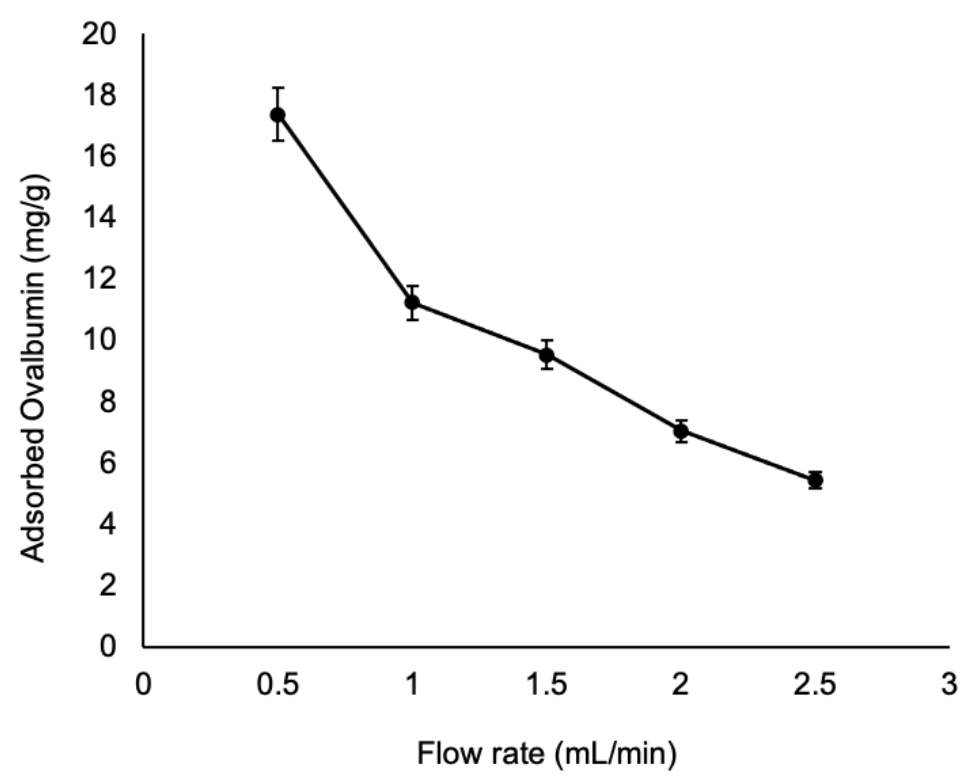

Figure 3. Effect of flow rate ( $\mathrm{pH} 5.5$ acetate buffer, $\left.\mathrm{T}: 25^{\circ} \mathrm{C}\right)$.

Ovalbumin aqueous solutions were prepared at different concentrations $(0.1-2.5 \mathrm{mg} / \mathrm{mL})$ and the effect of the initial concentration of ovalbumin was investigated for OVA imprinted and non-imprinted cryogels. The adsorption capacity of ovalbumin molecules to MIP-1, MIP-2, MIP-3 and NIP cryogels increased with increasing concentrations of ovalbumin. With the increase in the ovalbumin concentration, the adsorption value increased too. But, at $1.5 \mathrm{mg} / \mathrm{mL}$ of ovalbumin concentration, a saturation value was reached. This is due to the saturation of the binding cavities on the ovalbumin imprinted cryogels. The maximum ovalbumin adsorption capacities of NIP and MIP-1, MIP-2 and MIP-3 cryogels were found as $3.23,18.99,28.99$ and $37.78 \mathrm{mg} / \mathrm{g}$, respectively. (Figure 4). It was found that the maximum ovalbumin adsorption capacity of MIP-3 was the highest due to the higher imprinted amount. After the ovalbumin rebinding, desorption studies were carried out using 1.0 $\mathrm{M} \mathrm{NaCl}$ solution and the amount of ovalbumin removed was determined spectrophotometrically at $280 \mathrm{~nm}$.

When the effect of ionic strength on the adsorption capacity of OVA imprinted cryogel was examined, the adsorption capacity of ovalbumin decreased from 11.23 to $3.03 \mathrm{mg} / \mathrm{g}$ OVA imprinted cryogel with the increasing concentration of $\mathrm{NaCl}$ (Figure 5). This decrease in adsorption capacity with increasing ionic strength occurs in affinity interactions due to electrostatic interactions between ovalbumin molecules and the monomer and ovalbumin in the MIP-3 cryogel [45].
The effect of temperature on the adsorption capacity of OVA imprinted cryogel was studied at different temperature $\left(4-45^{\circ} \mathrm{C}\right)$. As seen in Figure 6, a decrease in the adsorption capacity of OVA imprinted cryogel was observed with increasing temperature. While the kinetic energy of ovalbumin molecules increases with the increase in temperature, the hydrogen bonds and ionic interaction between the monomer to ovalbumin resulting in decreasing of adsorption capacity [46]. The adsorption capacity of OVA imprinted cryogel (MIP-3) decreased from 15.50 to $6.77 \mathrm{mg} / \mathrm{g}$ with increasing temperature.

One of the most important features of molecularly imprinted polymers is that they can be used over and over. This depends on the interaction between the analyte molecule and the adsorbent and the desorption efficiency of the adsorbed molecule [46]. The reusability of ovalbumin imprinted cryogel with the MIP-3 code number was achieved by performing an adsorption-desorption cycle from the ovalbumin aqueous solution 10 times. After each adsorption-desorption cycle, ovalbumin imprinted cryogel was desorbed with $1.0 \mathrm{M} \mathrm{NaCl}$ solution. As seen in figure 7, it was observed that there was no significant decrease in the adsorption capacity of MIP-3 cryogel.

One of the most experiments for determining the selectivity of OVA imprinted cryogel is the selectivity experiments. The selectivity parameters describe the 


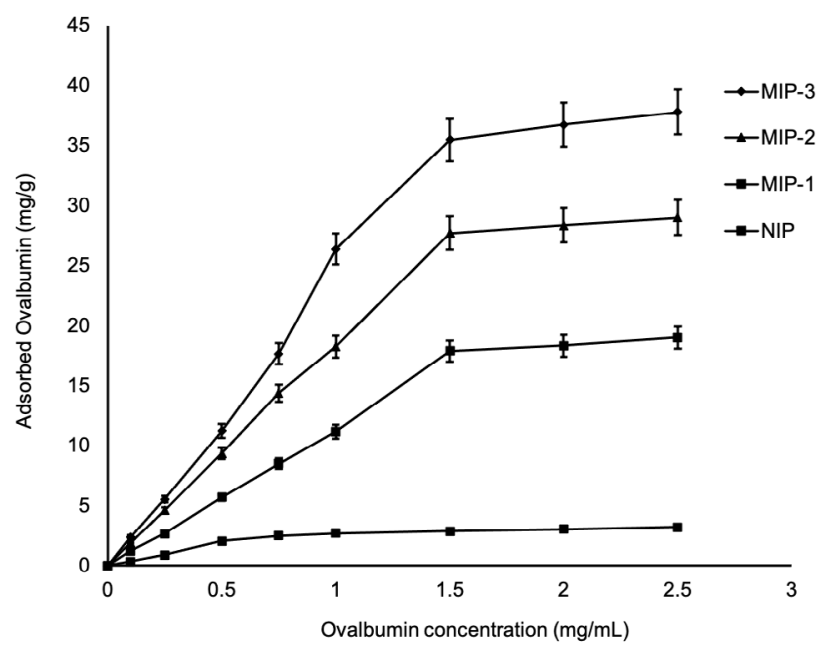

Figure 4. Effect of ovalbumin adsorption capacities (flow rate: $0.5 \mathrm{~mL} / \mathrm{min}, \mathrm{pH} 5.5$ acetate buffer, $\mathrm{T:} 25^{\circ} \mathrm{C}$ ).

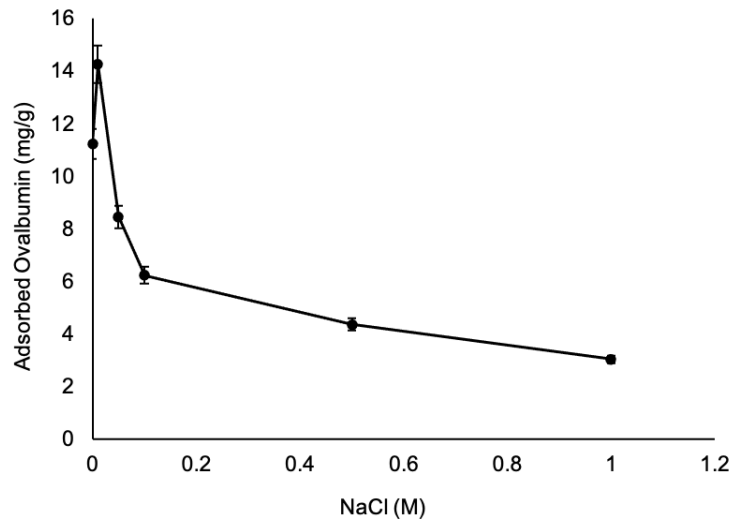

Figure 5. Effect of ionic strength (flow rate: $0.5 \mathrm{~mL} / \mathrm{min}, \mathrm{pH} 5.5$ acetate buffer, $\mathrm{T}: 25^{\circ} \mathrm{C}$ ).

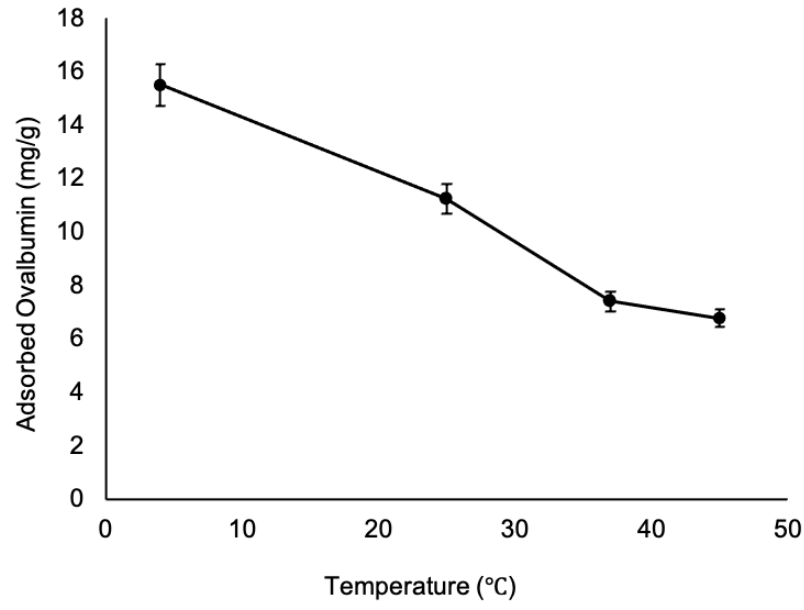

Figure 6. Effect of temperature (flow rate: $0.5 \mathrm{~mL} / \mathrm{min}, \mathrm{pH} 5.5$ acetate buffer). 


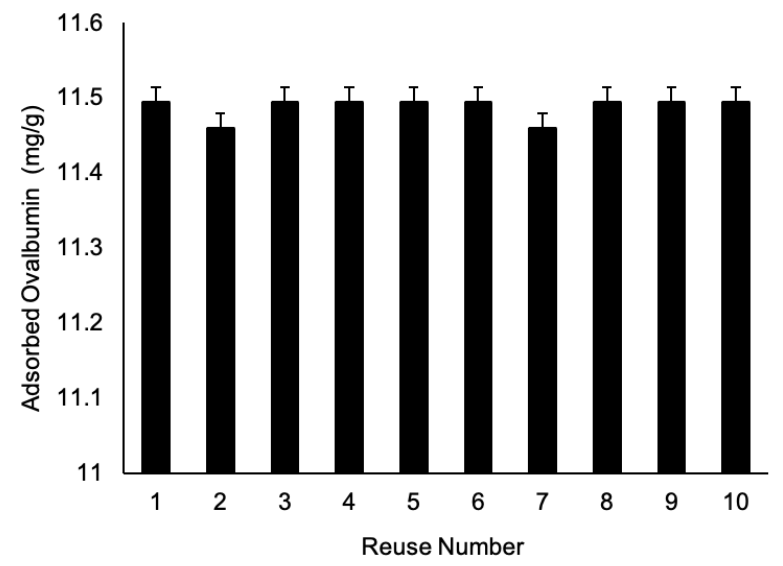

Figure 7. Effect of reusability (flow rate: $0.5 \mathrm{~mL} / \mathrm{min}, \mathrm{pH} 5.5$ acetate buffer, $\mathrm{T:} 25^{\circ} \mathrm{C}$ ).

imprinting efficiency of the adsorbents and the interactions of template molecules with the imprinted cavities [47]. TF and Lyz were selected as competing molecules for the selectivity of OVA imprinted and non-imprinted cryogels. The selectivity studies were carried out at ovalbumin concentration of $0.5 \mathrm{mg} / \mathrm{mL}$. The highest adsorption capacity of OVA imprinted cryogels for OVA, TF and Lyz is $11.227,0.834$ and $0.347 \mathrm{mg} / \mathrm{g}$, respectively (Figure 8). The adsorption capacity of ovalbumin nonimprinted cryogels for OVA, TF and Lyz is 1.586, 0.959 and $0.862 \mathrm{mg} / \mathrm{g}$, respectively (Figure 8 ). As seen in the Table 2, it was clearly seen that the adsorption capacity of MIP-3 cryogel for OVA was higher than that of NIP cryogel.

After purification of ovalbumin from egg white, its molecular weight and purity were checked by SDS-PAGE analysis (Figure 9). The lanes 1, 2, and 3 are the final (egg white after adsorption), eluted (sample desorbed after ovalbumin adsorption) and initial (egg white prior to adsorption) samples, respectively. The ovalbumin amount was clearly decreased in lane 1 (final) compared to lane 3 (initial) after binding onto ovalbumin imprinted cryogel. The desorption process of the OVA imprinted cryogel after adsorption and the purity of ovalbumin was proved by the presence of the band in lane 2. It has been observed that ovalbumin suppressed cryogel provides an effective method with high adsorption capacity and high selectivity for ovalbumin purified from egg white. The separation gel was scanned using an ImageQuant 300 (Amersham, USA) and then analyzed using ImageQuant Software (Molecular Dynamics). Data analysis was performed to calculate the purity of protein based on the percentage of ovalbumin to total protein staining $[22,46]$. The purity of the desorbed ovalbumin was about $85.4 \%$ and the recovery was about $77.6 \%$.

The recovery was calculated using Eq. (6) [48].

$\%$ Recovery $=\left(\frac{\mathrm{C}_{\text {adsorbed }}-\mathrm{C}_{\text {recovered }}}{\mathrm{C}_{\text {adsorbed }}}\right) * 100$

Table 2. Selectivity parameter values of MIP-3 and NIP cryogels.

\begin{tabular}{ccccccc}
\hline & \multicolumn{3}{c}{$\begin{array}{c}\text { MIP-3 } \\
\text { cryogel }\end{array}$} & \multicolumn{3}{c}{$\begin{array}{c}\text { NIP } \\
\text { cryogel }\end{array}$} \\
\hline OVA & $\mathrm{K}_{\mathrm{d}}$ & $\mathrm{k}$ & $\mathrm{K}$ & $\mathrm{k}$ & $\mathrm{k}^{\prime}$ \\
\hline TF & 5.132 & - & 0.719 & - & - \\
\hline Lyz & 3.559 & 1.442 & 2.145 & 0.335 & 4.304 \\
\hline
\end{tabular}




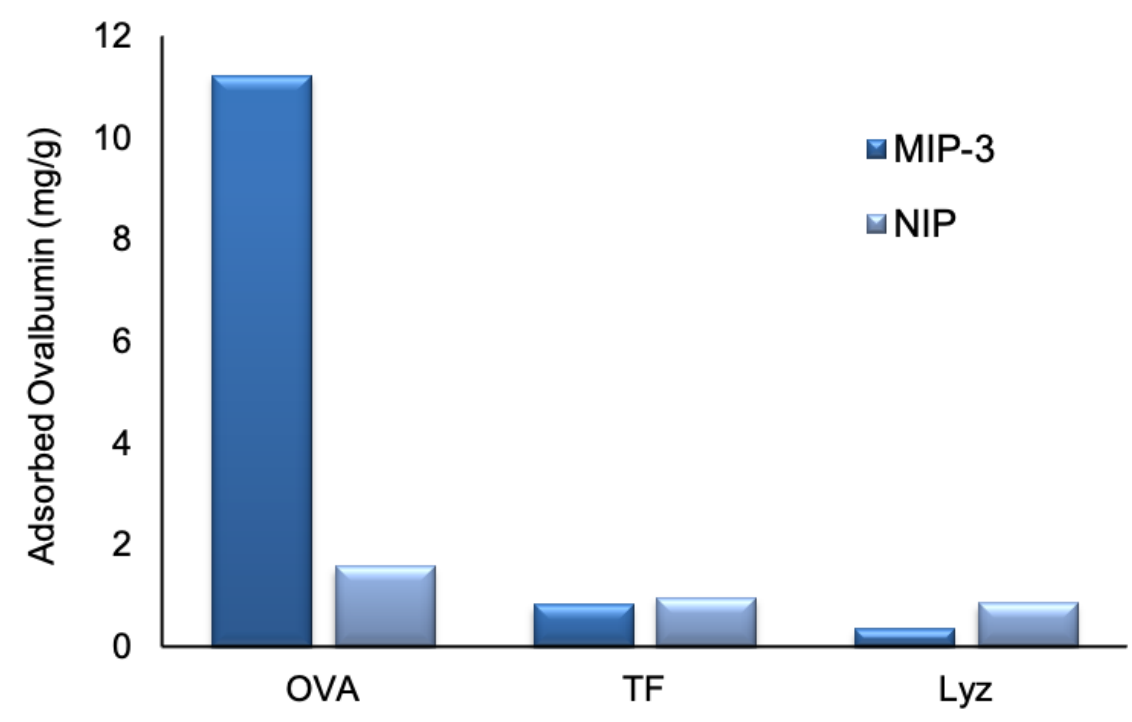

Figure 8. Competitive adsorption of ovalbumin (flow rate: $0.5 \mathrm{~mL} / \mathrm{min}$, phosphate buffer $\mathrm{pH} 5.5, \mathrm{~T}: 25^{\circ} \mathrm{C}$ ).

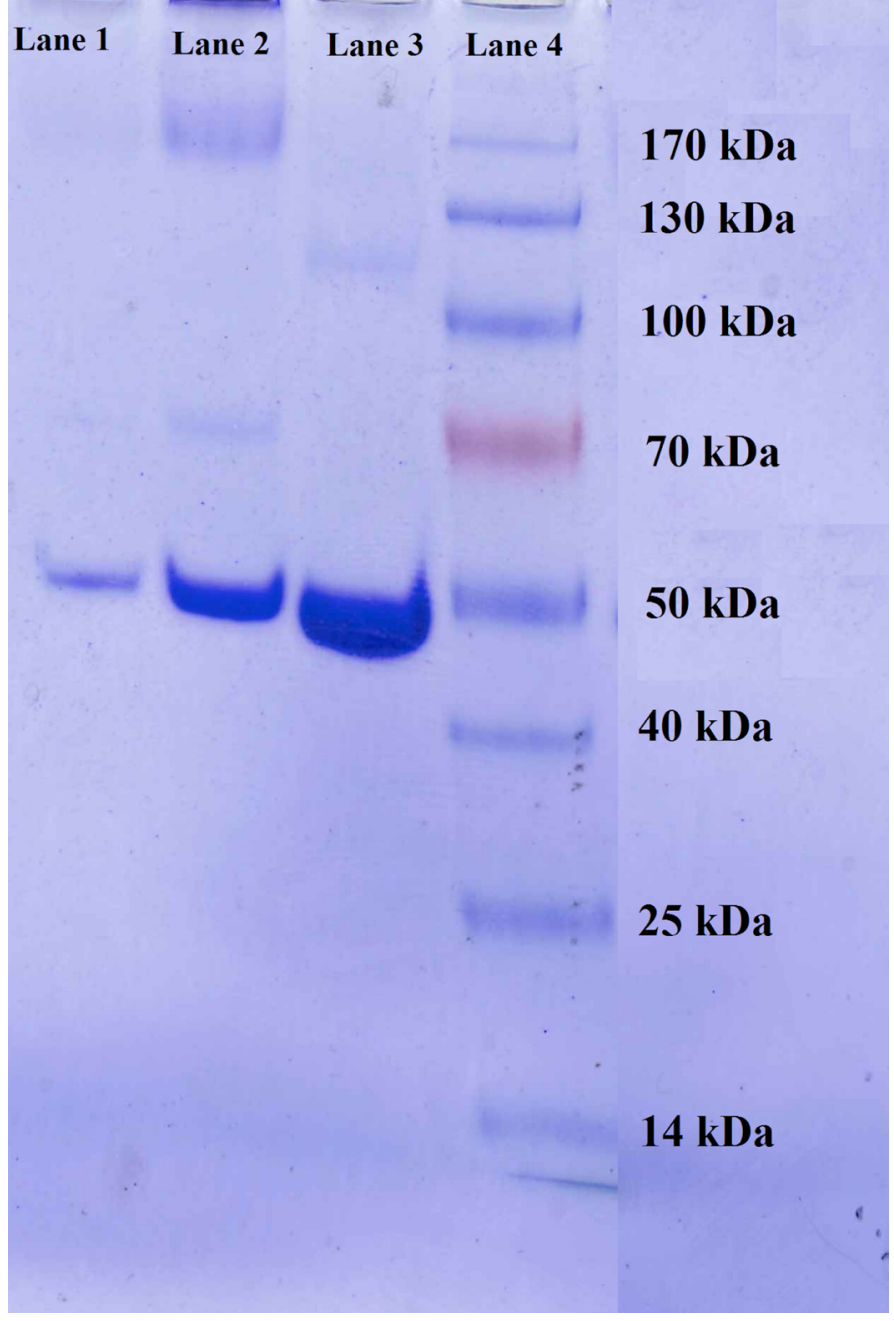

Figure 9. SDS-PAGE image (Lane 1: Egg white after adsorption (final), Lane 2: Sample desorbed after ovalbumin adsorption (eluted), Lane 3: Egg white prior to adsorption (initial), Lane: 4 Biomarker (Fermentas)). 


\section{CONCLUSIONS}

Ovalbumin is an important glycoprotein that causes food allergy, especially in infants. Therefore, it is important to purify ovalbumin from natural sources [49]. In this study, OVA imprinted cryogels were prepared for purification of ovalbumin. Cryogels are produced at low temperatures, polymerization, which forms the macroporous polymer structure with large interconnected pores. Cryogels have spongy morphology. The most important features that distinguish cryogels from other conventional matrices are their large porous structure, short diffusion path, and retention time. Recently, cryogels are accepted as the new generation fixed phase in separation technique [50]. Some studies on the purification of ovalbumin in the literature are summarized as follows. Geng et al. [51] used olyethylene glycol (PEG) precipitation and isoelectric precipitation methods for ovalbumin purification. Initially, ovalbumin was separated from ovomucin, ovotransferrin and ovomucoid from chicken egg white under experimental conditions (PEG concentration 15\%, pH 6.5, salt concentration $100 \mathrm{mmol} / \mathrm{L}$, and temperature $10^{\circ} \mathrm{C}$ ). The purity of ovalbumin in chicken egg white were analyzed by HPLC with a retention time of $14.5 \mathrm{~min}$. Ovalbumin was obtained with a yield of 46.4 and a purity of $95.1 \%$ from chicken egg white. Zheng et al. [52] prepared tungstotellurate(VI)-coated magnetic nanoparticles for separation and purification of ovalbumin in egg white. The prepared magnetic nanoparticles were characterized with with infrared spectroscopy, energy dispersive spectroscopy and scanning electron microscopy. The maximum adsorption efficiency is $91.6 \%$ for $100 \mu \mathrm{g} / \mathrm{mL}$ ovalbumin solution. Pereira et al. [53] investigated the selectivity of ovalbumin from egg white from polyethylene glycols (PEG) with different molecular weights and potassium citrate/citric acid solutions prepared in different $\mathrm{pH}$ buffers. $\mathrm{pH}$ buffers, PEG molecular weight and the amount of phase forming components were optimized for the selective extraction of ovalbumin in the aqueous biphasic systems. Ovalbumin purity and yield were determined using sodium dodecyl sulfate polyacrylamide gel electrophoresis (SDS-PAGE) and size exclusion high performance liquid chromatography (SE-HPLC) methods. According to the experimental results, it was confirmed that ovalbumin purification from egg white was achieved completely in one step with a recovery yield of $65 \%$. Jiang et al. [54] was purified ovalbumin from salted egg white by the aqueous two phase flotation method. $\mathrm{n}$ this study, an aqueous two-phase flotation consisting of ammonium sulfate $\left(\left(\mathrm{NH}_{4}\right)_{2} \mathrm{SO}_{4}\right)$ and polyethylene glycols (PEG) was applied in order to reduce the contamination of salted egg white treated as waste and by-products in the production of salted egg yolk. The effects of PEG and $\left(\mathrm{NH}_{4}\right)_{2} \mathrm{SO}_{4}$ concentration, flow rate and flotation time on flotation efficiency and purity of ovalbumin were investigated. Under optimal experimental conditions, the flotation efficiency $(\mathrm{Y})$ and purity $(\mathrm{P})$ of ovalbumin was calculated to be 82.15 $\pm 0.24 \%$ and $92.98 \pm 0.68 \%$, respectively. Croguennec et al. [55] developed a simple and fast procedure based on the frontal chromatography principle for the purification of ovalbumin from egg white using an anion exchanger. Two hundred and fifty milliliters of Q-sepharose FF gel were isocratically separated with $9.55 \mathrm{~g}$ of ovalbumin extracted with $0.5 \mathrm{M} \mathrm{NaCl}$ at $83 \%$ purity. In addition, 94\% ovalbumin purity was recovered by an isocratic elution using $0.14 \mathrm{M}$ $\mathrm{NaCl}$. In this study, the parameters effecting the capacity of ovalbumin adsorption were investigated with ovalbumin aqueous solutions and egg white. OVA imprinted and non-imprinted cryogels were prepared for ovalbumin purification from egg white. The maximum ovalbumin adsorption capacity of OVA imprinted cryogel (MIP-3) was found to be $37.78 \mathrm{mg} / \mathrm{g}$ from aqueous solutions. The reusability of OVA imprinted cryogels was tested by performing 10 times adsorption-desorption cycles. Additionally, the purified ovalbumin from egg white was performed by SDS-PAGE using a $12 \%$ separation gel and the recovery was about $77.6 \%$. When the experimental results are examined, it is seen that the study is a useful and promising method that can be applied in ovalbumin purification from egg white.

\section{References}

1. J.A. Huntington, P.E. Stein, Structure and properties of ovalbumin, J. Chromatogr. B Biomed. Sci. Appl., 756 (2001) 189-198.

2. M.D.A. Dantas, H.A. Tenório, Thiago I.B. Lopes, H.J.V. Pereira, A.J. Marsaioli, I.M. Figueiredo, J.C.C. Santos, Interactions of tetracyclines with ovalbumin, the main allergen protein from egg white: Spectroscopic and electrophoretic studies, Int. J. Biol. Macromol., 102 (2017) 505-514.

3. X. Fu, Q. Liu, C. Tang, J. Luo, X. Wu, L. Lu, Z. Cai, Study on structural, rheological and foaming properties of ovalbumin by ultrasound-assisted glycation with xylose, Ultrason, Sonochem., 58 (2019) 104644.

4. J. Milošević, J. Petrić, B. Jovčić, B. Janković, N. Polović, Exploring the potential of infrared spectroscopy in qualitative and quantitative monitoring of ovalbumin amyloid fibrillation, Spectrochim. Acta A Mol Biomol. Spectrosc., 229 (2020) 117882.

5. J.A. Huntington, P.E. Stein, Structure and properties of ovalbumin, J. Chromatogr. B, 756 (2001) 189-198.

6. E.D. Abeyrathne, H.Y. Lee, D.U. Ahn, Egg white proteins and their potential use in food processing or as nutraceutical and pharmaceutical agents-a review, Poult. Sci. J., 92 (2013), 3292-3299.

7. H.Y. Park, T.J. Yoon, H.H. Kim, Y.S. Han, H.D. Choi, Changes in the antigenicity and allergenicity of ovalbumin in chicken egg white by $\mathrm{N}$-acetylglucosaminidase, Food Chem., 217 (2017) 342-345. 
8. L.Z. Sun, S. Elsayed, T.B. Aasen, T. Van Do, N.P. Aardal, E. Florvaag, K. Vaali, Comparison between ovalbumin and ovalbumin peptide 323-339 responses in allergic mice: Humoral and cellular aspects, Scand. J. Immunol., 71 (2010) 329-335.

9. W.H. Yang, Z.C. Tu, H. Wang, X. Li, M. Tian, High-intensity ultrasound enhances the immunoglobulin IgG and IgE binding of ovalbumin, J. Sci. Food Agric., 97 (2017) 2714 2720.

10. M.M. Pereira, R.A.P. Cruz, M.R. Almeida, Á.S. Lima, J.A.P. Coutinho, M.G. Freire, Single-step purification of ovalbumin from egg white using aqueous biphasic systems, Process Biochem., 51 (2016) 781-791.

11. N. Habibi, S. Christau, L.J. Ochyl, Z. Fan, A.H. Najafabadi, M. Kuehnhammer, M. Zhang, M. Helgeson, R. Klitzing, J.J. Moon, J. Lahann, Engineered ovalbumin nanoparticles for cancer immunotherapy, Adv. Therap., 3 (2020) 2000100.

12. W. Zou, F.K. Mourad, X. Zhang, D.U. Ahn, Z. Cai, Y. Jin, Phase separation behavior and characterization of ovalbumin and propylene glycol alginate complex coacervates, Food Hydrocoll., 108 (2020) 105978.

13. V. Verhasselt, J. Genuneit, J.R. Metcalfe, M.K. Tulic, A. Rekima, D.J. Palmer, S.L. Prescott, Ovalbumin in breastmilk is associated with a decreased risk of IgE-mediated egg allergy in children, Allergy., 75 (2020) 1463-1466.

14. I. Roy, M.V. S. Rao, M.N. Gupta, An integrated process for purification of lysozyme, ovalbumin, and ovomucoid from hen egg white, Appl. Biochemi. Biotechnol., 111 (2003) 5563.

15. B. Jiang, J. Na, L. Wang, D. Li, C. Liu, Z. Feng, Eco-innovation in reusing food by-products: Separation of ovalbumin from salted egg white using aqueous two-phase system of PEG 1000/(NH4)2SO4, Polymers, 11 (2019) 238.

16. K. Liu, S. Chen, H. Chen, P. Tong, J. Gao, Cross-linked ovalbumin catalyzed by polyphenol oxidase: Preparation, structure and potential allergenicity, Int. J. Biol. Macromol., 107 (2018) 2057-2064

17. S. Jalili-Firoozinezhad, M. Filippi, F. Mohabatpour, D. Letourneur, A. Scherberich, Chicken egg white: Hatching of a new old biomaterial, Mater. Today Commun., 40 (2020) 193-214.

18. H. Xia, L. Wang, C. Li, B. Tian, Q. Li, H. Zhao, Q. Bai, Synthesis of fully porous silica microspheres with high specific surface area for fast HPLC separation of intact proteins and digests of ovalbumin, Microchim. Acta, 187 (2020) 382.

19. H. Wang, Q. Sun, J. Tan, Y. Hu, W. Yan, Z. Li, Z. Tu, Conformational alteration and the glycated sites in ovalbumin during vacuum freeze-drying induced glycation: A study using conventional spectrometry and liquid chromatography high resolution mass spectrometry, Food Chem., 318 (2020) 126519

20. F. Füss, A. Criscuolo, K. Cook, K. Scheffler, J. Bones, Cracking proteoform complexity of ovalbumin with anion-exchange chromatography high-resolution mass spectrometry under native conditions, J. Proteome Res., 18 (2019) 3689-3702.

21. B. Jiang, J. Na, L. Wang, D. Li, C. Liu, Z. Feng, Reutilization of food waste: One-step extration, purification and characterization of ovalbumin from salted egg white by aqueous two-phase flotation, Foods, 8 (2019) 286.

22. D. Çimen, A. Denizli, Immobilize metal affinity monolithic cryogels for cytochrome C purification, Colloids Surf. B: Biointerfaces, 93 (2012) 29-35.

23. V.M. Gun'ko, I.N. Savina, S.V. Mikhalovsky, Cryogels: Morphological, structural and adsorption characterization, Adv. Coll. Int. Sci., 187 (2013) 1-46.
24. Y. Saylan, A. Denizli A. Supermacroporous composite cryogels in biomedical applications, Gels, 5 (2019) 20.

25. A. Memic, T. Colombani, L.J. Eggermont, M. Rezaeeyazdi, J. Steingold, Z.J. Rogers, K.J. Navare, H.S. Mohammed, S.A. Bencherif, Latest advances in cryogel technology for biomedical applications, Adv. Therap., 2 (2019) 1800114.

26. Z.J. Rogers, S.A. Bencherif, Cryogelation and cryogels, Gels, 5 (2019) 46.

27. V.I. Lozinsky, I.Y. Galaev, F.M. Plieva, I.N. Savina, H. Jungvid, B. Mattiasson, Polymeric cryogels as promising materials of biotechnological interest, Trends Biotechnol., 21 (2003) 445-451.

28. V.I. Lozinsky, A brief history of polymeric cryogels, Adv. Polym. Sci., 263 (2014) 1-48.

29. A. Kumar, Supermacroporous cryogels: biomedical and biotechnological applications, Taylor Francis, 480 (2016) 52.

30. D. Çimen, N. Bereli, M. Andaç, A. Denizli, Molecularly imprinted cryogel columns for Concanavalin A purification from jack bean extract, Sep Sci plus., (2018) 1-10.

31. S. Asliyüce, N. Bereli, L. Uzun, M.A. Onur, R. Say, A. Denizli, lon-imprinted supermacroporous cryogel, for in vitro removal of iron out of human plasma with beta thalassemia, Sep. Purif. Technol., 73 (2010) 243-249.

32. G. Baydemir, N. Bereli, M. Andaç, R. Say, I.Y. Galaev, A. Denizli, Supermacroporous poly(hydroxyethyl methacrylate) based cryogel with embedded bilirubin imprinted particles, React. Funct. Polym., 69 (2009) 36-42.

33. M. Andac, I.Y. Galaev, A. Denizli, Affinity based and molecularly imprinted cryogels: Applications in biomacromolecule purification, J. Chromatogr. B, 1021 (2016) 69-80.

34. N. Bereli, H. Yavuz, A. Denizli, A. Protein chromatography by molecular imprinted cryogels, J. Liq Chrom. Relat. Tech., 43 (2020) 657-670.

35. Y. Cui, Z. He, Y. Xu, Y. Su, L. Ding, Y. Li, Fabrication of molecularly imprinted polymers with tunable adsorption capability based on solvent-responsive cross-linker, Chem. Eng. J., 405 (2021) 126608.

36. D. Çimen, I. Göktürk, F. Yılmaz, Removal of iron by chelation with molecularly imprinted supermacroporous cryogel, Artif. Cells Nanomed. Biotechnol., 44 (2016) 1158-1166.

37. X. Zhou, W. Li, X. He, L. Chen, Recent advances in the study of protein imprinting, Sep. Purif. Rev., 36 (2007) 257-283.

38. T. Takeuchi, T. Hishiya, Molecular imprinting of proteins emerging as a tool for protein recognition, Org. Biomol. Chem., 6 (2008) 2459-2467.

39. T.S. Bedwell, N. Anjum, Y. Ma, J. Czulak, A. Poma, E. Piletska, M.J. Whitcombe, S.A. Piletsky, New Protocol for optimization of polymer composition for imprinting of peptides and proteins, RSC Adv., 9 (2009) 27849-27855.

40. A.A. Al-Tubuly, SDS-PAGE and Western Blotting, Methods Mol. Med., 40 (2000) 391-405.

41. Y. Shimazaki, A. Takahashi, Antibacterial activity of lysozymebinding proteins from chicken egg white, J. Microbiol. Methods, 154 (2018) 19-24.

42. K.V. Abrosimova, O.V. Shulenina, S.V. Paston, FTIR study of secondary structure of bovine serum albumin and ovalbumin, J. Phys. Conf. Ser. 769 (2016) 012016.

43. N. Xiao, W.H.Y. Tu, N. Xiao, W. He, Y. Zhao, Y. Yao, M. Xu, H. Du, $\mathrm{N}$. Wu, Y. Tu, Effect of $\mathrm{pH}$ and xanthan gum on emulsifying property of ovalbumin stabilized oil-in water emulsions, LWT., 147 (2021) 111621.

44. I. Perçin, G. Şener, A.H. Demirçelik, N. Bereli, A. Denizli, Comparison of two different reactive dye immobilized PHEMA cryogel discs for purification of lysozyme, Appl. Biochem. Biotechnol., 175 (2015) 2795-2805. 
45. K. Hamade, I. Göktürk, N. Bereli, D. Türkmen, A. Elkak, A. Denizli, A dye-affinity cryogel membrane for malate dehydrogenase purification from Saccharomyces cerevisiae, J. Biomater. Sci. Polym. Ed., 31 (2020) 38-52.

46. B. Demirci, N. Bereli, S. Aslıyüce, G. Baydemir, A. Denizli, A. (2017). Protein c recognition by ion-coordinated imprinted monolithic cryogels, J. Sep. Sci., 40 (2017) 1610-1620.

47. N. Bereli, M. Andaç, G. Baydemir, R. Say, I.Y. Galaev, A Denizli, Protein recognition via ion-coordinated molecularly imprinted supermacroporous cryogels, J. Chromatogr. A, 1190 (2008) 18-26.

48. I. Bernabe, J.M. Gomez, E. Diez, P. Saez, A. Rodriguez, Optimization and adsorption-based recovery of cobalt using activated disordered mesoporous carbons, Adv. Mater. Sci. Eng., (2019) 1-10.

49. J. H. Lee, H. D. Paik, Anticancer and immunomodulatory activity of egg proteins and peptides: a review, Poult. Sci. 98 (2019) 6505-6516.

50. D. Çimen, D. Türkmen, A. Denizli, Poly-L-histidine immobilized cryogels for lysozyme purification, Adsorp. Sci. Technol., (2016) 1-19.
51. F. Geng, Y. Xie, J. Wang, S. Li, Y. Jin, M. Ma, Large-scale purification of ovalbumin using polyethylene glycol precipitation and isoelectric precipitation, Poult. Sci., 98 (2019), 1545-1550.

52. C. Zheng, Y. Shi-Yu, W. Nan, X. Jia-Wei, C. Qing, Preparation of tungstotellurate(VI)-coated magnetic nanoparticles for separation and purification of ovalbumin in egg white, Chinese J. Anal. Chem., 47 (2019) 1302-1308.

53. M.M. Pereira, R.A.P. Cruz, M.R. Almeida, Á.S. Lima, J.A.P. Coutinho, M.G. Freire, Single-step purification of ovalbumin from egg white using aqueous biphasic systems, Process Biochem., 51 (2016) 781-791.

54. B. Jiang, J. Na, L. Wang, D. Li, C. Liu, Z. Feng, Reutilization of food waste: One-step extration, purification and characterization of ovalbumin from salted egg white by aqueous two-phase flotation, Foods, 8 (2019) 286

55. T. Croguennec, F. Nau, S. Pezennec, G. Brule, Simple rapid procedure for preparation of large quantities of ovalbumin, J. Agric. Food. Chem., 48 (2000) 4883-4889. 